\title{
Efficacy of Adjuvant Treatment for Fracture Nonunion/Delayed Union: A Network Meta-Analysis of Randomized Controlled Trials
}

Jun Yang

Yuxi Municipal Hospital of TCM

Xiangmin Zhang

Yuxi Municipal Hospital of TCM

Wangbo Liang ( $\sim$ liangwangbo@tom.com)

Yuxi Municipal Hospital of TCM

Guo Chen

Yuxi Municipal Hospital of TCM

Yanbo Ma

Yuxi Municipal Hospital of TCM

Yonghua Zhou

Yuxi Municipal Hospital of TCM

Rong Fen

Yuxi Municipal Hospital of TCM

Kaichang Jiang

Yuxi Municipal Hospital of TCM

Research Article

Keywords: Fracture, nonunion, delayed union, adjuvant treatment, meta-analysis

Posted Date: February 1st, 2022

DOI: https://doi.org/10.21203/rs.3.rs-1223939/v1

License: (c) (i) This work is licensed under a Creative Commons Attribution 4.0 International License. Read Full License 


\section{Abstract}

\section{Background}

Fracture nonunion/delayed union seriously affects physical and mental health and quality of life. The aim of this study was to evaluate the relative efficacy of different adjuvant treatments for nonunion/delayed union by network meta-analysis.

\section{Methods}

A comprehensive search was performed to identify randomized controlled trials (RCTs) evaluating adjuvant treatment in the management of nonunion/delayed union. A network meta-analysis reporting on healing rate, healing time, and adverse effect (AE) outcomes was conducted to assess and compare different interventions.

\section{Results}

Thirty studies were included in analysis. For healing rate outcome, bone marrow aspirate (BMA) + autologous cancellous bone (ACB) was found to be significantly better than ACB alone (Odds ratio: 0.12; 95\% confidence interval: $0.03,0.59$ ). In the ranking results, BMA+ platelet-rich plasma (PRP) (96\%), BMA+ACB (90\%), and BMA alone (82\%) showed relative advantages in healing rate. Low-intensity pulsed ultrasonography (LIUS) intervention significantly shortened the healing time compared with $A C B$ (Standardized mean difference: -8.93; 95\% confidence interval: -14.37, -3.48). LIUS (99\%), BMA+PRP (74\%), and bone morphogenetic proteins (BMPs) $(69 \%)$ have relative advantages.

\section{Conclusions}

Among the current intervention strategies, BMA and combination with PRP and ACB can improve the healing rate of nonunion/delayed union. LIUS can significantly shorten the healing time. However, large-scale, well-designed studies are still needed to confirm the results.

Trial registration: retrospectively registered

\section{Introduction}

Fracture nonunion is defined as a fracture that cannot heal in the expected time without further intervention [1]. Delayed union of fractures can be considered a sign of nonunion [2]. The clinical manifestations included persistent pain, instability of fracture fragments, and disability. As health care resources, the risk of nonunion/delayed union varies worldwide and is reported to be between $1.9 \%$ and $4.9 \%$ [3]. Either biological or mechanical factors can contribute to the occurrence of nonunion, which seriously affects physical and mental health and quality of life and increases health care costs and financial burdens to societies.

There is a lack of clinical and radiographic consensus on the standardized definition of nonunion $[4,5]$. The US Food and Drug Administration defines nonunion as a fracture that has failed to heal for at least 9 months and has shown no signs of healing for 3 consecutive months [6]. For clinicians, a simplified definition refers to a fracture that cannot be healed without further intervention [7]. The basic principle of treatment is to provide mechanical and biological support for bone nonunion. Fracture stabilization and immobilization are the primary conditions for treatment [8].

Autologous cancellous bone (ACB) grafts are considered the "gold standard" treatment; however, they are limited by pain at the donor site and potential damage to the arteries, nerves and tissues around the donor bone [9]. For nonunion, in addition to surgery and ACB transplantation, adjuvant therapy is also a method to improve the healing rate, including physiotherapy, bioactive substance treatment, and oral drugs [10].

In recent meta-analyses, various adjuvant strategies for nonunion were analyzed, in which the application of bone morphogenetic proteins (BMPs) can significantly shorten the healing time, but there are complications of heterotopic ossification [11, 12]. Plateletrich plasma (PRP) also accelerated nonunion healing, but bisphosphonate had no significant effect [6, 13]. In a network metaanalysis study, it was considered that low-intensity pulsed ultrasonography (LIUS) has more advantages than electrical 
stimulation in the healing effect of fresh fractures [14]. The aim of this study was to evaluate the relative efficacy of different adjuvant treatments for nonunion/delayed union by network meta-analysis.

\section{Methods}

This meta-analysis followed the Preferred Reporting Items for Systematic Reviews and Meta-Analyses (PRISMA) guidelines. Two authors separately conducted literature retrieval, study eligibility, data extraction, and quality assessment with inconsistency solved by discussion and decided by the corresponding author.

Literature search

A literature search of PubMed, EmBase, Cochrane, Ebscohost, and Scopus was performed from databases incipient to November 2021 for randomized controlled trials (RCTs) evaluating adjuvant treatment in the management of nonunion/delayed union. The brief retrieval formula was "(fracture) AND random* AND ((((Non-Union) OR (Delayed Union)) OR (Mal-Union)) OR (nonunion)) OR (nonunions))". The references of related reviews were also screened to prevent omissions.

Inclusion and exclusion criteria

Briefly, we included RCTs evaluating adjuvant therapy for patients with nonunion or delayed union. The inclusion criteria were as follows: 1 , the study was RCT design; 2 , nonunion/delayed union patients were analyzed; 3 , the intervention was adjuvant therapy; 4 , the control was another adjuvant therapy or blank control which was different from the intervention; 5, The outcome reported fracture healing rate and/or fracture healing time. The exclusion criteria were as follows: 1, intervention studies on fresh fractures; 2, animal and experimental studies; and 3, studies that did not report the predetermined outcomes. Furthermore, reviews, case reports, conference abstracts, editorials, and comments were also excluded.

Data extraction and quality assessment

The contents were extracted by two authors, and disagreements were resolved by consensus. The following data were extracted: the first author's name, publication year, study location, sample size, patients' average age, fracture site, clinical diagnosis, intervention, control and follow-up. The outcomes were radiographic/clinical healing rate, healing time, and adverse effect (AE). The methodological quality of the eligible studies was evaluated with the Cochrane risk of bias tool.

\section{Statistical analysis}

Discontinuous variables were pooled using odds ratios (ORs) with $95 \%$ confidence intervals (Cls), and continuous variables were pooled using standard mean differences (SMDs) with 95\% Cls. A random-effects network meta-analysis with a frequentist framework was adopted. Network plots were generated for each outcome, with nodes representing the type of therapeutic strategy, lines between nodes representing direct comparison, and edges of lines representing the precision of comparison. Inconsistency was locally assessed by calculating the difference between direct and indirect estimates in network analysis. For each outcome, we estimated the ranking probability of the therapeutic strategy being at each possible rank for each therapeutic strategy using a surface under the cumulative ranking curve (SUCRA). Comparison-adjusted funnel plots were used to determine the possible publication bias. $p<0.05$ was considered a significant difference, and data were analyzed by $R$ language (version 4.0 .3 ) with the "netmeta" package (version 1.5-0).

\section{Results}

Literature search

In this study, 2035 articles were identified after duplications were removed. After screening the titles and abstracts, 1907 articles were excluded. The full texts of the remaining 128 articles were assessed. The following articles were excluded due to: reviews (55); study about nonadjuvant therapy (18); study on fresh fracture (10); conference abstract (6); duplicate publication (2); study about same therapeutic strategies (2); no predetermined outcomes reported (2); comments (2); study on children congenital anomaly (1). Finally, thirty studies were included in the analysis [15-44] (Figure 1). 
The inclusion study was published from 1984 to 2020. The research is mainly located in Asia, North America, and Europe. The sample size from each study was relatively small, with a maximum of 140 patients. One study included adolescent patients [17]; however, we do not think it will impact the overall results. The interventions analyzed included physiotherapy (LIPU, extracorporeal shock wave (ESWT), electromagnetic field (EMF) therapy), and bioactive substance treatment (PRP, BMP, bone marrow aspirate (BMA, including mesenchymal stem cells)). and oral drugs (strontium ranelate (Protelos), Chinese traditional medicine (CTM)). The average follow-up period ranged from 3 months to 7.6 years (Table 1). After comprehensive consideration of the risk of bias, although all studies were RCT designs, the major factor affecting the quality was the lack of blindness of patients and intervention personnel, as well as the blindness of the outcome assessor. This may lead to a subjective influence on the healing judgment, which makes the results tend to be positive (Figure 2). 
Table 1

Characteristics of the included studies.

\begin{tabular}{|c|c|c|c|c|c|c|c|}
\hline Study & Location & $\begin{array}{l}\text { Sample } \\
\text { size }\end{array}$ & Average age & $\begin{array}{l}\text { Fracture } \\
\text { site }\end{array}$ & Interventions & Control & $\begin{array}{l}\text { Follow- } \\
\text { up }\end{array}$ \\
\hline $\begin{array}{l}\text { Tang YF } \\
2020[15]\end{array}$ & China & 66 & $20-56$ & Tibia & $\mathrm{PRP}+\mathrm{BMA}$ & BMA & $\begin{array}{l}16-36 \\
\text { Month }\end{array}$ \\
\hline $\begin{array}{l}\text { Marion } \\
\text { Mühldorfer- } \\
\text { Fodor 2020[16] }\end{array}$ & Germany & 68 & $29(16-60)$ & Scaphoid & EWST+ACB & ACB & $\begin{array}{l}24 \\
\text { Weeks }\end{array}$ \\
\hline $\begin{array}{l}\text { Ahmad I } \\
2020[17]\end{array}$ & Pakistan & 101 & $31.46 \pm 13.9$ & $\begin{array}{l}\text { Tibia } \\
\text { (major) }\end{array}$ & PROTELOS & CONTROL & $\begin{array}{l}3 \\
\text { Months }\end{array}$ \\
\hline $\begin{array}{l}\text { Samuel G } \\
\text { 2018[18] }\end{array}$ & Indian & 40 & $34.3 \pm 9.49 ; 39.35 \pm 10 . .39$ & $\begin{array}{l}\text { Tibia } \\
\text { (major) }\end{array}$ & PRP & CONTROL & $\begin{array}{l}36 \\
\text { Weeks }\end{array}$ \\
\hline $\begin{array}{l}\text { Carlos AO } \\
\text { 2017[19] }\end{array}$ & Germany & 16 & $37.14 \pm 10.22 ; 38.88 \pm 15.36$ & Humerus & $\mathrm{PRP}+\mathrm{ACB}$ & ACB & $\begin{array}{l}36 \\
\text { Weeks }\end{array}$ \\
\hline $\begin{array}{l}\text { Hernigou P } \\
\text { 2017[20] }\end{array}$ & France & 80 & $41.2 \pm 18.2$ & Tibia & $\mathrm{BMA}+\mathrm{ACB}$ & ACB & $\begin{array}{l}7.6(5- \\
10) \\
\text { Years }\end{array}$ \\
\hline $\begin{array}{l}\text { Zhang S } \\
2017[21]\end{array}$ & China & 47 & $38.29 \pm 7.49 ; 36.57 \pm 8.31$ & $\begin{array}{l}\text { Tibia } \\
\text { (major) }\end{array}$ & $\mathrm{PRP}+\mathrm{BMA}$ & BMA & $\begin{array}{l}9-15 \\
\text { Months }\end{array}$ \\
\hline $\begin{array}{l}\text { Zhao ZC } \\
2017[22]\end{array}$ & China & 92 & $18-70$ & Femur & PRP & CONTROL & $\begin{array}{l}12 \\
\text { Months }\end{array}$ \\
\hline $\begin{array}{l}\text { Ghaffarpasand } \\
\text { F 2016[23] }\end{array}$ & Iran & 75 & $26.5 \pm 5.8 ; 26.3 \pm 6.2$ & $\begin{array}{l}\text { Femur, } \\
\text { Tibia }\end{array}$ & PRP & CONTROL & $\begin{array}{l}12 \\
\text { Months }\end{array}$ \\
\hline $\begin{array}{l}\text { Zhang H } \\
2016[24]\end{array}$ & China & 24 & $33.45 ; 32.69$ & Tibia & BMA & CONTROL & $\begin{array}{l}\text { 12-34 } \\
\text { Months }\end{array}$ \\
\hline $\begin{array}{l}\text { Streit A } \\
2016[25]\end{array}$ & usa & 8 & $47(24-63)$ & $\begin{array}{l}\text { Fifth } \\
\text { metatarsal }\end{array}$ & EMF & CONTROL & $\begin{array}{l}24 \\
\text { Weeks }\end{array}$ \\
\hline $\begin{array}{l}\text { Christian von } \\
\text { Ruden } \\
2016[26]\end{array}$ & Germany & 49 & $44(19-77)$ & $\begin{array}{l}\text { Ulnar, } \\
\text { Radial }\end{array}$ & $\mathrm{BMP}+\mathrm{ACB}$ & ACB & $\begin{array}{l}6 \\
\text { Months }\end{array}$ \\
\hline $\begin{array}{l}\text { Zhai L } \\
\text { 2016[27] }\end{array}$ & China & 63 & $39.6(23-50) ; 38.1(20-49)$ & $\begin{array}{l}\text { Femur, } \\
\text { Tibia }\end{array}$ & BMA+ESWT & ESWT & $\begin{array}{l}12 \\
\text { Months }\end{array}$ \\
\hline $\begin{array}{l}\text { Shi HF } \\
\text { 2013[28] }\end{array}$ & China & 58 & $41.1 \pm 14.5 ; 38.4 \pm 11.6$ & $\begin{array}{l}\text { Femur, } \\
\text { Tibia }\end{array}$ & EMF & CONTROL & $\begin{array}{l}3 \\
\text { Months }\end{array}$ \\
\hline $\begin{array}{l}\text { Huang ZJ } \\
2011[29]\end{array}$ & China & 64 & $47.3 \pm 22.2$ & $\begin{array}{l}\text { Ulna or } \\
\text { radius } \\
\text { (major) }\end{array}$ & CTM & CONTROL & $\begin{array}{l}3 \\
\text { Months }\end{array}$ \\
\hline $\begin{array}{l}\text { Schofer MD } \\
2010[30]\end{array}$ & USA & 101 & $42.6 \pm 14.6 ; 45.1 \pm 11.9$ & Tibia & LIUS & CONTROL & $\begin{array}{l}16 \\
\text { Weeks }\end{array}$ \\
\hline
\end{tabular}

Abbreviations: ACB: autologous cancellous bone; BMA: bone marrow aspirate; BMP: bone morphogenetic proteins; CTM: Chinese traditional medicine; EMF: electromagnetic fields; ESWT: extracorporeal shock wave; LIUS: Low-intensity pulsed ultrasonography; PROTELOS = Strontium ranelate; PRP: Platelet-Rich Plasma.

*Consider, if feasible to do so, reporting the number of records identified from each database or register searched (rather than the total number across all databases/registers).

**If automation tools were used, indicate how many records were excluded by a human and how many were excluded by automation tools.

From: Page MJ, McKenzie JE, Bossuyt PM, Boutron I, Hoffmann TC, Mulrow CD, et al. The PRISMA 2020 statement: an updated guideline for reporting systematic reviews. BMJ 2021;372:n71. doi: 10.1136/bmj.n71

For more information, visit: http://www.prisma-statement.org/ 


\begin{tabular}{|c|c|c|c|c|c|c|c|}
\hline Study & Location & $\begin{array}{l}\text { Sample } \\
\text { size }\end{array}$ & Average age & $\begin{array}{l}\text { Fracture } \\
\text { site }\end{array}$ & Interventions & Control & $\begin{array}{l}\text { Follow- } \\
\text { up }\end{array}$ \\
\hline $\begin{array}{l}\text { Yuan JG } \\
2010[31]\end{array}$ & China & 140 & $34 \pm 2$ & $\begin{array}{l}\text { Humerus, } \\
\text { Tibia }\end{array}$ & BMA & ACB & $\begin{array}{l}3 \\
\text { Months }\end{array}$ \\
\hline $\begin{array}{l}\text { Sun YP } \\
2009[32]\end{array}$ & China & 40 & $43 \pm 6$ & $\begin{array}{l}\text { Tibia } \\
\text { (major) }\end{array}$ & $\mathrm{BMP}+\mathrm{ACB}$ & ACB & $\begin{array}{l}11-20 \\
\text { Months }\end{array}$ \\
\hline $\begin{array}{l}\text { Angelo } \\
\text { Cacchio } \\
2009[33]\end{array}$ & Italy & 126 & $42.7 \pm 5.9$ & $\begin{array}{l}\text { Tibia } \\
\text { Femur }\end{array}$ & ESWT & CONTROL & $\begin{array}{l}24 \\
\text { Months }\end{array}$ \\
\hline $\begin{array}{l}\text { Rutten S } \\
2008[34]\end{array}$ & Netherlands & 13 & $42-63$ & Fibula & LIUS & CONTROL & $\begin{array}{l}3 \\
\text { Months }\end{array}$ \\
\hline $\begin{array}{l}\text { G.M Calori } \\
2008[35]\end{array}$ & Italy & 120 & $43(19-65)$ & $\begin{array}{l}\text { Humerus, } \\
\text { Tibia } \\
\text { (major) }\end{array}$ & BMP & PRP & $\begin{array}{l}9 \\
\text { Months }\end{array}$ \\
\hline $\begin{array}{l}\text { Bilic R } \\
2006[36]\end{array}$ & Croatia & 18 & $23 \pm 5 ; 22 \pm 5 ; 19 \pm 4$ & Scaphoid & $\mathrm{BMP}+\mathrm{ACB}$ & ACB & $\begin{array}{l}24 \\
\text { Months }\end{array}$ \\
\hline $\begin{array}{l}\text { Ricardo M } \\
2006[37]\end{array}$ & France & 21 & $26.7(17-42)$ & Scaphoid & LIUS & CONTROL & $\begin{array}{l}1-4 \\
\text { Years }\end{array}$ \\
\hline $\begin{array}{l}\text { Calori GM } \\
2006[38]\end{array}$ & Italy & 29 & $47 \pm 2.56 ; 35.3 \pm 1.76$ & $\begin{array}{l}\text { Femur, } \\
\text { Tibia }\end{array}$ & BMP & PRP & $\begin{array}{l}9 \\
\text { Months }\end{array}$ \\
\hline $\begin{array}{l}\text { Simonis RB } \\
\text { 2002[39] }\end{array}$ & UK & 34 & $32(16-61)$ & Tibia & EMF & CONTROL & $\begin{array}{l}6 \\
\text { Months }\end{array}$ \\
\hline $\begin{array}{l}\text { Friedlaender } \\
\text { GE 2001[40] }\end{array}$ & USA & 122 & $38 \pm 16 ; 34 \pm 11$ & Tibia & $\mathrm{BMP}+\mathrm{ACB}$ & ACB & $\begin{array}{l}24 \\
\text { Months }\end{array}$ \\
\hline $\begin{array}{l}\text { Cook SD } \\
1999[41]\end{array}$ & USA & 30 & na & Tibia & BMP & ACB & $\begin{array}{l}9 \\
\text { Months }\end{array}$ \\
\hline $\begin{array}{l}\text { Scott G } \\
1994[42]\end{array}$ & UK & 23 & $43(23-87)$ & $\begin{array}{l}\text { Femur, } \\
\text { Tibia }\end{array}$ & EMF & CONTROL & $\begin{array}{l}6 \\
\text { Months }\end{array}$ \\
\hline $\begin{array}{l}\text { Sharrard WJW } \\
1990[43]\end{array}$ & UK & 51 & $34.7(18-84) ; 45.4(18-76)$ & Tibia & EMF & CONTROL & $\begin{array}{l}12 \\
\text { Weeks }\end{array}$ \\
\hline $\begin{array}{l}\text { Barker AT } \\
\text { 1984[44] }\end{array}$ & UK & 17 & $34(19-72)$ & Tibia & EMF & CONTROL & $\begin{array}{l}48 \\
\text { Weeks }\end{array}$ \\
\hline \multicolumn{8}{|c|}{$\begin{array}{l}\text { Abbreviations: ACB: autologous cancellous bone; BMA: bone marrow aspirate; BMP: bone morphogenetic proteins; CTM: } \\
\text { Chinese traditional medicine; EMF: electromagnetic fields; ESWT: extracorporeal shock wave; LIUS: Low-intensity pulsed } \\
\text { ultrasonography; PROTELOS = Strontium ranelate; PRP: Platelet-Rich Plasma. }\end{array}$} \\
\hline \multicolumn{8}{|c|}{$\begin{array}{l}\text { *Consider, if feasible to do so, reporting the number of records identified from each database or register searched (rather than } \\
\text { the total number across all databases/registers). }\end{array}$} \\
\hline \multicolumn{8}{|c|}{$\begin{array}{l}\star \star \text { If automation tools were used, indicate how many records were excluded by a human and how many were excluded by } \\
\text { automation tools. }\end{array}$} \\
\hline \multicolumn{8}{|c|}{$\begin{array}{l}\text { From: Page MJ, McKenzie JE, Bossuyt PM, Boutron I, Hoffmann TC, Mulrow CD, et al. The PRISMA } 2020 \text { statement: an } \\
\text { updated guideline for reporting systematic reviews. BMJ 2021;372:n71. doi: 10.1136/bmj.n71 }\end{array}$} \\
\hline \multicolumn{8}{|c|}{ For more information, visit: http://www.prisma-statement.org/ } \\
\hline
\end{tabular}

In the classification of adjuvant therapeutic strategies, for long bone nonunion treatment, surgical stabilization was necessary, but for short bones, it was not. Therefore, surgical fixation was adopted according to actual needs and not considered in strategies. However, ACB, as the gold standard treatment, might affect adjuvant therapy and is considered a strategy. In addition, it should be noted that in the healing rate outcome, both intervention groups might achieve fracture healing during the follow-up period. In this case, the healing time is an important supplement to assess adjuvant therapy effects. 
For healing rate outcome, 15 intervention strategies were analyzed, including ACB, BMA, BMP, CTM, EMF, ESWT, LIUS, PROTELOS, PRP, their combinations, and blank control (Figure 3, A). In pairwise comparisons, except ESWT (OR: 1.76; 95\% Cl: 0.24, 13.00) and BMA+ESWT (OR: 0.79; 95\% Cl: 0.15, 4.27), which were not significantly different from the blank control, the other strategies were significantly better than the control. Compared to ACB, only BMA+ACB was found to be significantly better (OR: $0.12 ; 95 \% \mathrm{Cl}$ : 0.03 , 0.59). In the SUCRA ranking results, BMA+PRP (96\%), BMA+ACB (90\%), and BMA alone (82\%) showed relative advantages in healing rate (Figure 4, A). A comparison-adjusted funnel plot did not show potential publication bias (Figure 5, A).

For the healing time, a total of 13 intervention strategies were analyzed, including ACB, BMA, BMP, CTM, EMF, EWST, LIUS, PRP, their combination, and blank control (Figure 3, B). In the pairwise comparison, BMP (SMD: -2.61; 95\% Cl: -5.01, 0.22) and LIUS (SMD: -8.85; 95\% Cl: $-12.85,-4.86)$ interventions had significantly shorter healing times than the blank control. Compared with ACB, only LIUS intervention significantly shortened the healing time (SMD: -8.93; 95\% Cl: -14.37, -3.48). In the SUCRA ranking results, LIUS (99\%), PRP+BMA (74\%), and BMP (69\%) had relative advantages (Figure 4, B). No publication bias was detected according to the funnel plot (Figure 5, B).

For AE outcome, a total of 7 intervention strategies were analyzed, including ACB, BMA, BMA+ACB, BMP, EMF, ESWT, PRP, and control (Figure 3, C). Compared with the control, EMF (OR: 13.21; 95\% Cl: 1.58, 110.40) and ESWT (OR: 4.90; 95\% Cl: 1.38, 17.43) had higher AE risk. In the SUCRA ranking results, BMA+ACB (95\%) had relatively few side effects (Figure 4, C). Although no publication bias was detected (Figure $5, \mathrm{C}$ ), the AE results included malunion, infection, reoperation, and adverse drug reaction with high heterogeneity.

\section{Discussion}

In this study, adjuvant treatments for fracture nonunion/delayed union were comprehensively analyzed by network meta-analysis. Adjuvant therapeutic strategies include ACB, BMA, BMP, CTM, EMF, ESWT, LIUS, PROTELOS, PRP, and their combinations. In the healing rate results, $B M A+P R P, B M A+A C B$, and $B M A$ have relative advantages that support BMA application in nonunion/delayed union treatment. The healing time results showed that LIUS and BMP, especially LIUS, could significantly shorten the healing time. In the AE results, it was considered that EMF and ESWT interventions may bring a high risk of AE.

BMA harvested from bone marrow includes multiple types of progenitor cells and is injected into the fracture site, which is considered a useful treatment for bone regeneration. Centrifugal concentration is beneficial to improve the effect [45]. Especially for atrophic nonunion, the proliferation and osteogenic differentiation ability of mesenchymal stem cells were inhibited, and BMA was beneficial to supplement more active mesenchymal stem cells [46]. Generally, long bone nonunion and delayed union treatment require surgical intervention, BMA is easier to obtain and local application. Therefore, compared to other cell therapyrelated diseases, it has the advantage of convenience. BMA mainly has three application strategies, including intraoperative injection, transplantation after in vitro expansion, and soaked ACB or other bone graft materials [47, 48]. However, after expansion, multiple injections to the fracture site are needed, and osteofascial compartment syndrome should be specially considered. In addition to BMA and BMA+ACB, BMA+PRP also achieved ideal effects. PRP contains active cytokine components, such as platelet derived growth factor and vascular endothelial growth factor, which can further promote osteogenic-angiogenic coupling in bone formation with BMA [49].

LIUS is a physical intervention approved by the FDA for nonunion treatment [50 11216689]. As extracorporeal equipment, pressure waves could be delivered transcutaneously to the fracture site with slight heat. Its mechanism may vary, including the promotion of bone regeneration, angiogenesis, and nerve regeneration [51,52]. The results of this study also suggested that it may be the only intervention to shorten the healing time of nonunion/delayed union compared with ACB.

BMPs are the most widely used growth factors in bone nonunion, especially BMP2. It has been confirmed to be successful in new bone formation, but heterotopic ossification is also a major problem in clinical application. In this study, BMPs significantly shortened the healing time without increasing the AE risk or even tended to reduce the occurrence. However, supraphysiological dose application and the lack of a controlled delivery system lead to heterotopic ossification that needs well-planned surgical excision [53-55]. This serious AE still raises concern in the clinical application of BMP.

Limitations

Page 7/16 
The presented study has several limitations. First, this study was performed at the study level, instead of at the individual level, and hypertrophic nonunion and atrophic nonunion patients could not be analyzed in subgroups. Second, there was no limited place at the time of study publication, but a long-time span (nearly 40 years) may bring about great changes in medical conditions. Third, the study included different types of nonunion/delayed union, including long and short bone fractures, so there was heterogeneity among the studies. Fourth, radiographic healing was adopted as a priority, and clinical healing was also adopted if radiographic healing was not reported. Fifth, the impact of drug dosage or electromagnetic intensity on fracture healing was not assessed due to the small number of eligible studies.

\section{Conclusions}

In summary, this study showed that among the current intervention strategies, BMA and combination with PRP and ACB can improve the healing rate of nonunion/delayed union. LIUS can significantly shorten the healing time. However, large-scale, welldesigned studies are still needed to confirm the results.

\section{Abbreviations}

\section{ACB}

autologous cancellous bone

$\mathrm{AE}$

adverse effect

BMA

bone marrow aspirate

BMPs

bone morphogenetic proteins

CTM

Chinese traditional medicine

EMF

electromagnetic field

ESWT

extracorporeal shock wave

LIUS

low-intensity pulsed ultrasonography

OR

Odds ratio

PRISMA

Preferred Reporting Items for Systematic Reviews and Meta-Analyses

PRP

platelet-rich plasma

RCTs

randomized controlled trials

SMD

standardized Mean difference

SUCRA

surface under the cumulative ranking curve

\section{Declarations}

\section{Ethics approval and consent to participate}

Not applicable 


\section{Consent for publication}

Not applicable

\section{Availability of data and materials}

All data generated or analyzed during this study are presented in this published article and its additional information files. Metaanalysis data can be requested from corresponding author.

\section{Competing interests}

The authors declare that they have no competing interests.

\section{Funding}

None

\section{Authors' contributions}

WL and GC were responsible for the conception and design, data synthesis and analysis, interpretation of data and drafting the manuscript. XZ and YM screened the literature and assessed risk of bias independently. JY, YZ, RF, and KJ contributed to conception and design, supervised the project, validated the data, reviewed and edited the manuscript. All authors read and approved the final manuscript.

\section{Acknowledgements}

None

\section{References}

1. Benshabat D, Factor S, Maman E, Khoury A, Krespi R, Ashkenazi I, et al. Addition of Bone Marrow Aspirate Concentrate Resulted in High Rate of Healing and Good Functional Outcomes in the Treatment of Clavicle Fracture Nonunion: A Retrospective Case Series. J Clin Med. 2021;10(20):1.

2. Sahu RL. Percutaneous autogenous bone marrow injection for delayed union or nonunion of long bone fractures after internal fixation. Rev Bras Ortop. 2018;53(6):668-673.

3. Wildemann B, Ignatius A, Leung F, Taitsman LA, Smith RM, Pesantez R, et al. Nonunion bone fractures. Nat Rev Dis Primers. 2021;7(1):57.

4. Meesters DM, Wijnands KAP, Brink PRG, Poeze M. Malnutrition and Fracture Healing: Are Specific Deficiencies in Amino Acids Important in Nonunion Development? Nutrients. 2018;10(11):1.

5. Stewart S, Darwood A, Masouros S, Higgins C, Ramasamy A. Mechanotransduction in osteogenesis. Bone Joint Res. 2020;9(1):1-14.

6. Andersen C, Wragg NM, Shariatzadeh M, Wilson SL. The Use of Platelet-Rich Plasma (PRP) for the Management of Nonunion Fractures. Curr Osteoporos Rep. 2021;19(1):1-14.

7. Song J, Kim Y, Kweon OK, Kang BJ. Use of stem-cell sheets expressing bone morphogenetic protein-7 in the management of a nonunion radial fracture in a Toy Poodle. J Vet Sci. 2017;18(4):555-558.

8. Tecimel O, Bozkurt I, Cepni S, Yaman F, Firat A, Ocguder DA. The comparison of single plate and double plate fixation methods for treatment of humeral shaft nonunions. Jt Dis Relat Surg. 2021;32(1):67-74.

9. Kikuchi N, Yoshioka T, Arai N, Hyodo K, Kanamori A, Yamazaki M. A radiological study of bone remodeling with two different types of porous beta-tricalcium phosphate in humans. Sci Rep. 2020;10(1):19886.

10. Brown S, Nixon J, Ransom M, Gilberts R, Dewhirst N, McGinnis E, et al. Multiple Interventions for Diabetic Foot Ulcer Treatment Trial (MIDFUT): study protocol for a randomized controlled trial. BMJ Open. 2020;10(4):e035947. 
11. Chen AF, Huang K, Zhou YQ. [Autologous bone grafting versus bone morphogenetic protein treatment for nonunion of long bone fractures in adultsa Meta analysis]. Zhongguo Gu Shang. 2020;33(1):87-92.

12. Polmear MM, Anderson AB, Lanier PJ, Orr JD, Nesti LJ, Dunn JC. Bone Morphogenetic Protein in Scaphoid Nonunion: A Systematic Review. J Wrist Surg. 2021;10(3):184-189.

13. Ng AJ, Yue B, Joseph S, Richardson M. Delayed/nonunion of upper limb fractures with bisphosphonates: systematic review and recommendations. ANZ J Surg. 2014;84(4):218-224.

14. Ebrahim S, Mollon B, Bance S, Busse JW, Bhandari M. Low-intensity pulsed ultrasonography versus electrical stimulation for fracture healing: a systematic review and network meta-analysis. Can J Surg. 2014;57(3):E105-118.

15. Tang Y, Yang Y, Li H, Xi J, Li W, Yue C, et al. [Effectiveness of percutaneous injection of autologous concentrated bone marrow aspirate combined with platelet-rich plasma in treatment of delayed fracture healing]. Zhongguo Xiu Fu Chong Jian Wai Ke Za Zhi. 2020;34(9):1130-1135.

16. Muhldorfer-Fodor M, Wagner M, Kottmann T, van Schoonhoven J, Prommersberger KJ. [Comparison of scaphoid reconstruction with a nonvascularised bone graft, with and without shock waves; preliminary results]. Handchir Mikrochir Plast Chir. 2020;52(5):404-412.

17. Ahmad I, Ahmed A, Javed MI, Atta A, Dogar A, Akram R, et al. Role of strontium ranelate in healing of surgically fixed long bone fractures after delayed/nonunion: A double blind randomized controlled trial. Pakistan Journal of Surgery. 2020;36(4):333-338.

18. Samuel G, Menon J, Thimmaiah S, Behera G. Role of isolated percutaneous autologous platelet concentrate in delayed union of long bones. Eur J Orthop Surg Traumatol. 2018;28(5):985-990.

19. Acosta-Olivo C, Garza-Borjon A, Simental-Mendia M, Vilchez-Cavazos F, Tamez-Mata Y, Pena-Martinez V. Delayed union of humeral shaft fractures: comparison of autograft with and without platelet-rich plasma treatment: a randomized, single blinded clinical trial. Arch Orthop Trauma Surg. 2017;137(9):1247-1252.

20. Hernigou P, Dubory A, Homma Y, Flouzat Lachaniette CH, Chevallier N, Rouard H. Single-stage treatment of infected tibial nonunions and osteomyelitis with bone marrow granulocytes precursors protecting bone graft. Int Orthop. 2018;42(10):24432450.

21. Zhang S, Zhang T, Fu GH, Li SH, Zhou XR, Chen LK. Therapeutic effect of autologous platelet rich plasma combined with bone marrow mesenchymal stem cell transplantation on long shaft fracture bone nonunion. Chinese Journal of Tissue Engineering Research. 2017;21(29):4716-4721.

22. Zhao ZC, Li ZW, Yan HX, Tang BM, Li CL, Zhang QF, et al. Platelet-rich plasma combined with conventional surgery in the treatment of atrophic nonunion of femoral shaft fractures: study protocol for a prospective, randomized, controlled clinical trial. Chinese Journal of Tissue Engineering Research. 2017;21(28):4442-4447.

23. Ghaffarpasand F, Shahrezaei M, Dehghankhalili M. Effects of Platelet Rich Plasma on Healing Rate of Long Bone Nonunion Fractures: A Randomized Double-Blind Placebo Controlled Clinical Trial. Bull Emerg Trauma. 2016;4(3):134-140.

24. Zhang $\mathrm{H}$, Xue F, Jun Xiao H. llizarov method in combination with autologous mesenchymal stem cells from iliac crest shows improved outcome in tibial nonunion. Saudi J Biol Sci. 2018;25(4):819-825.

25. Streit A, Watson BC, Granata JD, Philbin TM, Lin HN, O'Connor JP, et al. Effect on Clinical Outcome and Growth Factor Synthesis With Adjunctive Use of Pulsed Electromagnetic Fields for Fifth Metatarsal Nonunion Fracture: A Double-Blind Randomized Study. Foot Ankle Int. 2016;37(9):919-923.

26. von Ruden C, Morgenstern M, Hierholzer C, Hackl S, Gradinger FL, Woltmann A, et al. The missing effect of human recombinant Bone Morphogenetic Proteins BMP-2 and BMP-7 in surgical treatment of aseptic forearm nonunion. Injury. 2016;47(4):919-924.

27. Zhai L, Ma XL, Jiang C, Zhang B, Liu ST, Xing GY. Human autologous mesenchymal stem cells with extracorporeal shock wave therapy for nonunion of long bones. Indian J Orthop. 2016;50(5):543-550.

28. Shi HF, Xiong J, Chen YX, Wang JF, Qiu XS, Wang YH, et al. Early application of pulsed electromagnetic field in the treatment of postoperative delayed union of long-bone fractures: a prospective randomized controlled study. BMC Musculoskelet Disord. 2013;14:35. 
29. Huang ZJ, Guan JZ, Xu YJ, Zhang LJ. Clinical research on zishengukang pill (see text) used to treat delayed union of fracture. J Tradit Chin Med. 2011;31(3):189-191.

30. Schofer MD, Block JE, Aigner J, Schmelz A. Improved healing response in delayed unions of the tibia with low-intensity pulsed ultrasound: results of a randomized sham-controlled trial. BMC Musculoskelet Disord. 2010;11:229.

31. Yang J, Zhang P, Pen X. Comparison of effect of electrohydraulic and electromagnetic extracorporeal shock waves on bone nonunions and fractare disunite. Chin J Rehabil Med. 2009;24(10):921-923.

32. Sun YP, Qiao GY, Wang YB, Liu YK, Ren HW, Pang LF, et al. Comparison between iliac autograft combined with bone morphogenetic protein and iliac autograft for bone nonunion. Journal of Clinical Rehabilitative Tissue Engineering Research. 2009;13(33):6465-6468.

33. Cacchio A, Giordano L, Colafarina O, Rompe JD, Tavernese E, loppolo F, et al. Extracorporeal shock-wave therapy compared with surgery for hypertrophic long-bone nonunions. J Bone Joint Surg Am. 2009;91(11):2589-2597.

34. Rutten S, Nolte PA, Korstjens CM, van Duin MA, Klein-Nulend J. Low-intensity pulsed ultrasound increases bone volume, osteoid thickness and mineral apposition rate in the area of fracture healing in patients with a delayed union of the osteotomized fibula. Bone. 2008;43(2):348-354.

35. Calori GM, Tagliabue L, Gala L, d'Imporzano M, Peretti G, Albisetti W. Application of rhBMP-7 and platelet-rich plasma in the treatment of long bone nonunions: a prospective randomized clinical study on 120 patients. Injury. 2008;39(12):1391-1402.

36. Bilic R, Simic P, Jelic M, Stern-Padovan R, Dodig D, van Meerdervoort HP, et al. Osteogenic protein-1 (BMP-7) accelerates healing of scaphoid nonunion with proximal pole sclerosis. Int Orthop. 2006;30(2):128-134.

37. Ricardo M. The effect of ultrasound on the healing of muscle-pediculated bone graft in scaphoid nonunion. Int Orthop. 2006;30(2):123-127.

38. Calori GM, D'Avino M, Tagliabue L, Albisetti W, d'Imporzano M, Peretti G. An ongoing research for evaluation of treatment with BMPs or AGFs in long bone nonunion: protocol description and preliminary results. Injury. 2006;37 Suppl 3:S43-50.

39. Simonis RB, Parnell EJ, Ray PS, Peacock JL. Electrical treatment of tibial nonunion: a prospective, randomized, double-blind trial. Injury. 2003;34(5):357-362.

40. Friedlaender GE, Perry CR, Cole JD, Cook SD, Cierny G, Muschler GF, et al. Osteogenic protein-1 (bone morphogenetic protein-7) in the treatment of tibial nonunions. J Bone Joint Surg Am. 2001;83-A Suppl 1(Pt 2):S151-158.

41. Cook SD. Preclinical and clinical evaluation of osteogenic protein-1 (BMP-7) in bony sites. Orthopedics. 1999;22(7):669-671.

42. Scott G, King JB. A prospective, double-blind trial of electrical capacitive coupling in the treatment of nonunion of long bones. J Bone Joint Surg Am. 1994;76(6):820-826.

43. Sharrard WJ. A double-blind trial of pulsed electromagnetic fields for delayed union of tibial fractures. J Bone Joint Surg Br. 1990;72(3):347-355.

44. Barker AT, Dixon RA, Sharrard WJ, Sutcliffe ML. Pulsed magnetic field therapy for tibial nonunion. Interim results of a doubleblind trial. Lancet. 1984;1(8384):994-996.

45. Hernigou P, Poignard A, Manicom O, Mathieu G, Rouard H. The use of percutaneous autologous bone marrow transplantation in nonunion and avascular necrosis of bone. J Bone Joint Surg Br. 2005;87(7):896-902.

46. El-Jawhari JJ, Kleftouris G, El-Sherbiny Y, Saleeb H, West RM, Jones E, et al. Defective Proliferation and Osteogenic Potential with Altered Immunoregulatory phenotype of Native Bone marrow-Multipotential Stromal Cells in Atrophic Fracture NonUnion. Sci Rep. 2019;9(1):17340.

47. Stanovici J, Le Nail LR, Brennan MA, Vidal L, Trichet V, Rosset $P$, et al. Bone regeneration strategies with bone marrow stromal cells in orthopedic surgery. Curr Res Transl Med. 2016;64(2):83-90.

48. Granchi D, Ciapetti G, Gomez-Barrena E, Rojewski M, Rosset P, Layrolle P, et al. Biomarkers of bone healing induced by a regenerative approach based on expanded bone marrow-derived mesenchymal stromal cells. Cytotherapy. 2019;21(8):870885.

49. Peng Y, Wu S, Li Y, Crane JL. Type H blood vessels in bone modeling and remodeling. Theranostics. 2020;10(1):426-436.

50. Rubin C, Bolander M, Ryaby JP, Hadjiargyrou M. The use of low-intensity ultrasound to accelerate the healing of fractures. J Bone Joint Surg Am. 2001;83(2):259-270. 
51. Lin G, Reed-Maldonado AB, Lin M, Xin Z, Lue TF. Effects and Mechanisms of Low-Intensity Pulsed Ultrasound for Chronic Prostatitis and Chronic Pelvic Pain Syndrome. Int J Mol Sci. 2016;17(7):ijms17071057.

52. Tan Y, Guo Y, Reed-Maldonado AB, Li Z, Lin G, Xia SJ, et al. Low-intensity pulsed ultrasound stimulates proliferation of stem/progenitor cells: what we need to know to translate basic science research into clinical applications. Asian J Androl. 2021;23(6):602-610.

53. Ranganathan K, Loder S, Agarwal S, Wong VW, Forsberg J, Davis TA, et al. Heterotopic Ossification: Basic-Science Principles and Clinical Correlates. J Bone Joint Surg Am. 2015;97(13):1101-1111.

54. Busch A, Jager M, Mayer C, Sowislok A. Functionalization of Synthetic Bone Substitutes. Int J Mol Sci. 2021;22(9):1.

55. Jann J, Gascon S, Roux S, Faucheux N. Influence of the TGF-beta Superfamily on Osteoclasts/Osteoblasts Balance in Physiological and Pathological Bone Conditions. Int J Mol Sci. 2020;21(20):1.

\section{Figures}

PRISMA 2020 flow diagram for new systematic reviews which included searches of databases and registers only

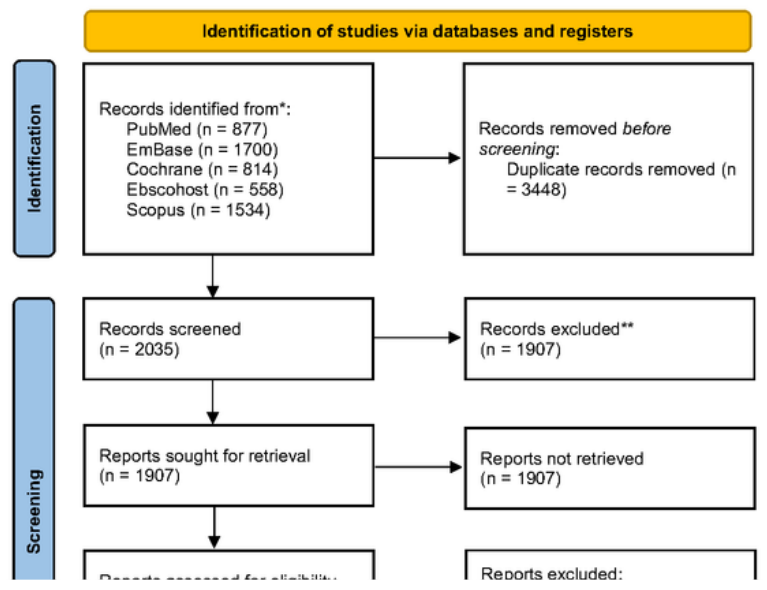

Figure 1 
Flowchart illustrating the literature search and the selection of included studies
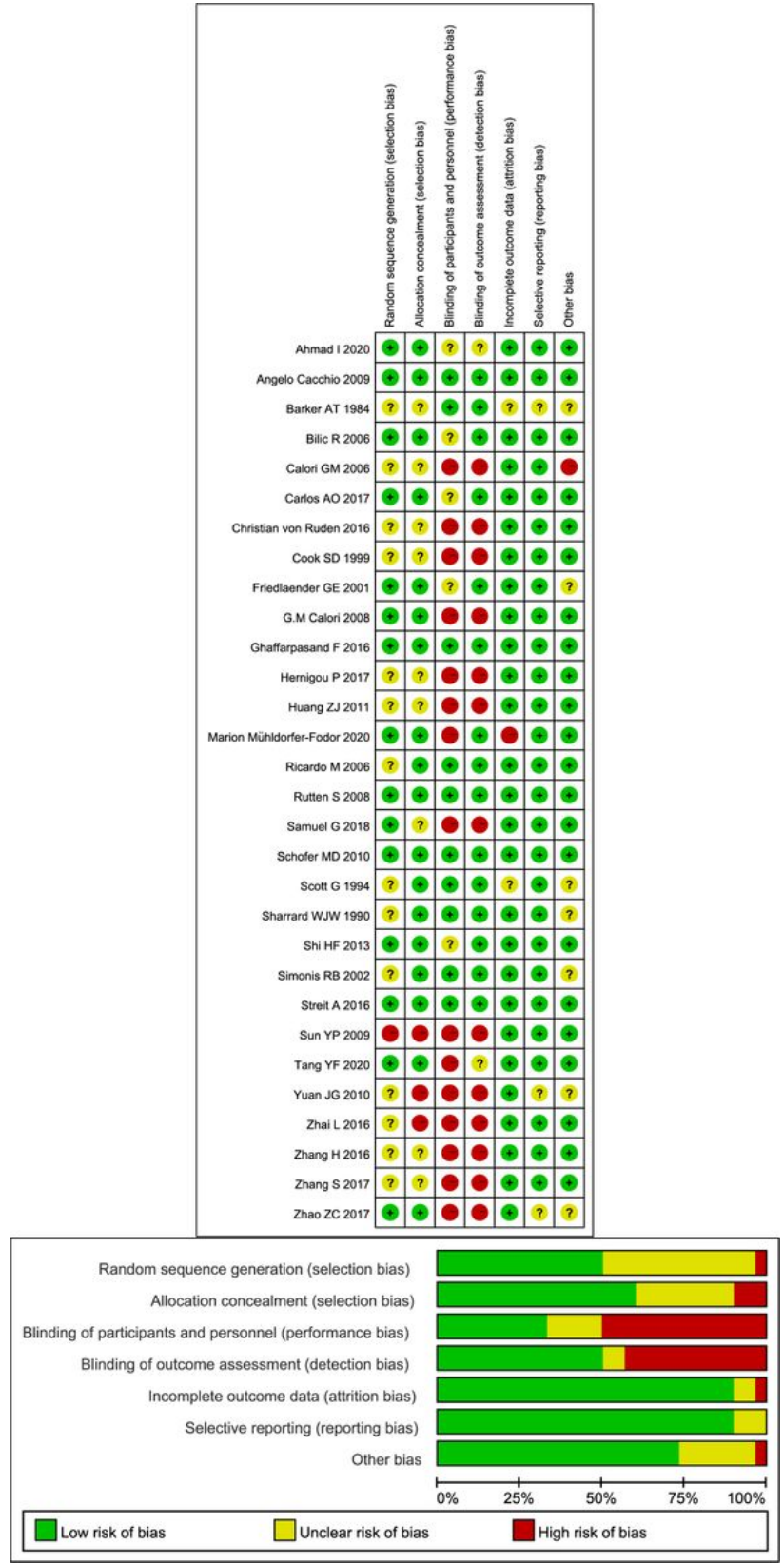

\section{Figure 2}

Risk of bias graph for each included study 
A

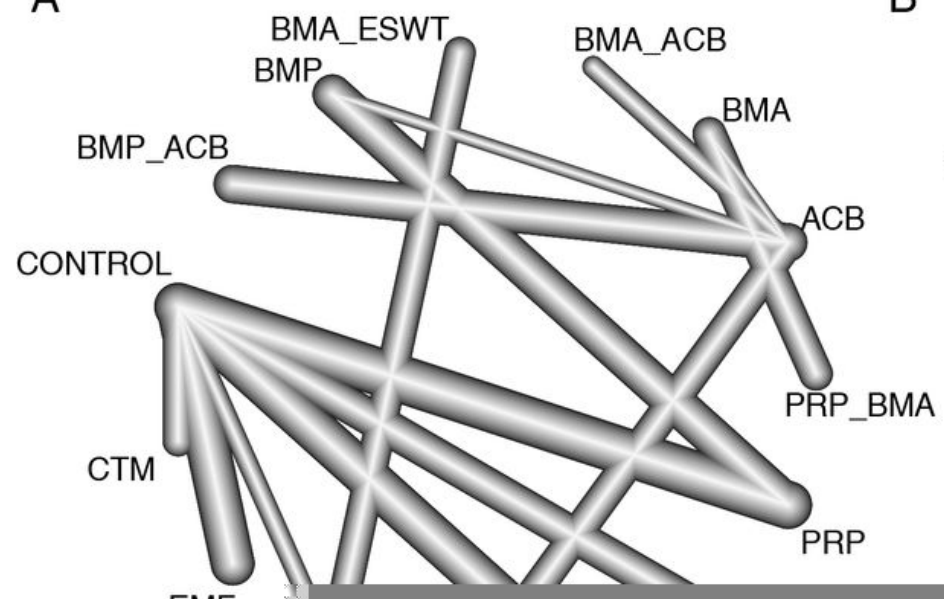

B

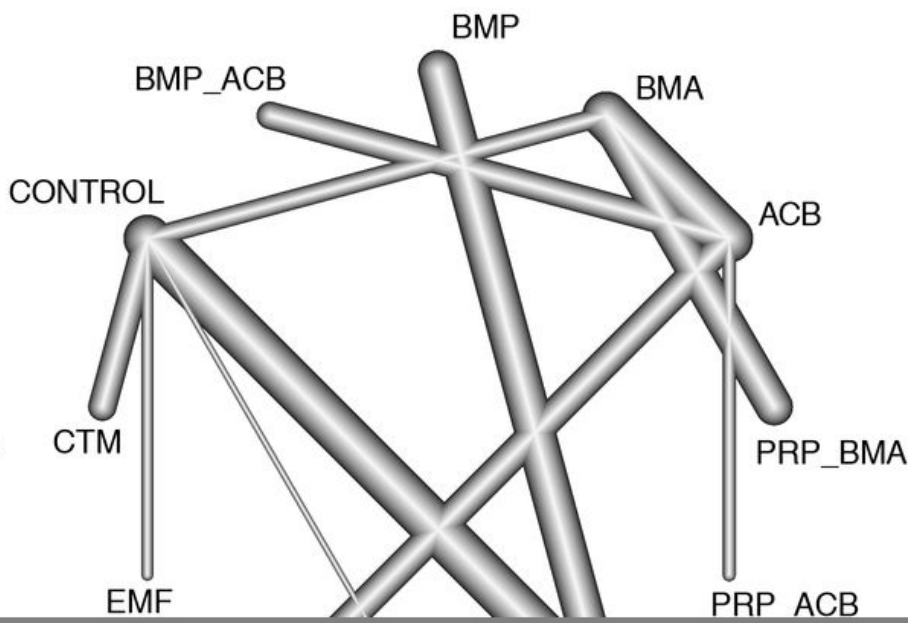

\section{Figure 3}

Network plots of the outcomes of therapeutic strategies on nonunion/delayed union in the network meta-analysis. A: healing rate; B: healing time; C: adverse effect. ACB: autologous cancellous bone; BMA: bone marrow aspirate; BMP: bone morphogenetic proteins; CTM: Chinese traditional medicine; EMF: electromagnetic fields; ESWT: extracorporeal shock wave; LIUS: low-intensity pulsed ultrasonography; PROTELOS = strontium ranelate; PRP: platelet-rich plasma. 
A

Comparison: other vs 'CONTROL'

Treatment (Random Effects Model)

ACB

BMA

BMA ACB

BMA_ESWT

BMP

BMP_ACB

CONTROL

CTM

EMF

ESWT

EINICT $\triangle \cap R$

(Random Effects Model)

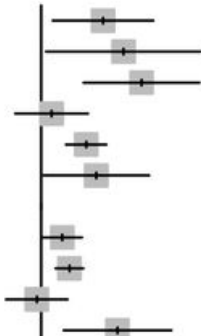

OR

95\%-CI SUCRA
$29.13 \quad[1.86 ; 456.82] \quad 0.69$

$237.19[9.95 ; 5653.07] \quad 0.88$

$1.76[0.24 ; 13.00] \quad 0.19$

$11.65 \quad[3.83 ; 35.45] \quad 0.55$

20.17 [1.12; 363.22] 0.64

1.00 [1.12; 363.22$] \quad 0.12$

$3.15 \quad[1.06 ; 9.36] \quad 0.33$

$4.69 \quad[2.17 ; 10.14] \quad 0.44$

$0.79 \quad[0.15 ; 4.27] \quad 0.06$

62 an $1225 \cdot 1017$ a 01076
$88.64[1.28 ; 6118.34] \quad 0.83$
B

\begin{tabular}{|c|c|c|c|c|}
\hline \multicolumn{5}{|c|}{ Comparison: other vs 'CONTROL' } \\
\hline Treatment & (Random Effects Model) & SMD & $95 \%-\mathrm{Cl}$ & JCRA \\
\hline ACB & 7 & 0.07 & {$[-3.63 ; 3.78]$} & 0.23 \\
\hline BMA & $\longrightarrow$ & -1.34 & {$[-4.02 ; 1.35]$} & 0.55 \\
\hline BMP & $\longrightarrow$ & -2.61 & {$[-5.01 ;-0.22]$} & 0.67 \\
\hline BMP_ACB & -4 & -0.79 & {$[-5.32 ; 3.74]$} & 0.40 \\
\hline CONTROL & & 0.00 & & 0.23 \\
\hline CTM & $\longrightarrow$ & -0.62 & {$[-3.22 ; 1.98]$} & 0.36 \\
\hline EMF & $\longrightarrow$ & -0.89 & {$[-3.85 ; 2.08]$} & 0.43 \\
\hline EWST_ACB & & -0.56 & {$[-5.09 ; 3.96]$} & 0.29 \\
\hline LIUS & 1. & -8.85 & {$[-12.85 ;-4.86]$} & 0.99 \\
\hline
\end{tabular}

\section{Figure 4}

Forest plot of network meta-analysis comparisons between therapeutic strategies and blank control. A: healing rate; $B$ : healing time; C: adverse effect. ACB: autologous cancellous bone; BMA: bone marrow aspirate; BMP: bone morphogenetic proteins; Cl: confidence interval; CTM: Chinese traditional medicine; EMF: electromagnetic fields; ESWT: extracorporeal shock wave; LIUS: lowintensity pulsed ultrasonography; OR: odds ratio; PROTELOS = strontium ranelate; PRP: platelet-rich plasma; SUCRA: surface under the cumulative ranking curve. 
A

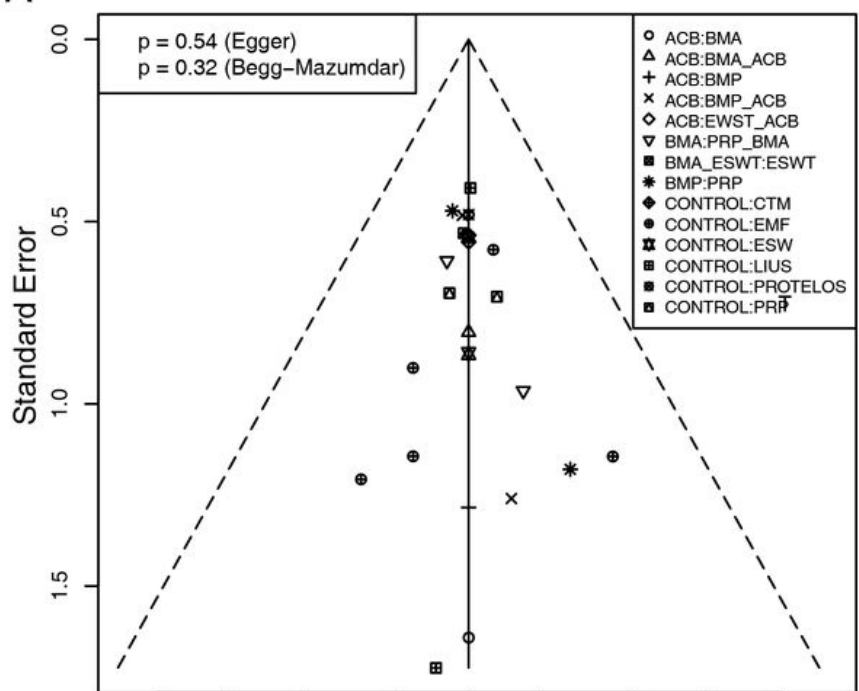

B

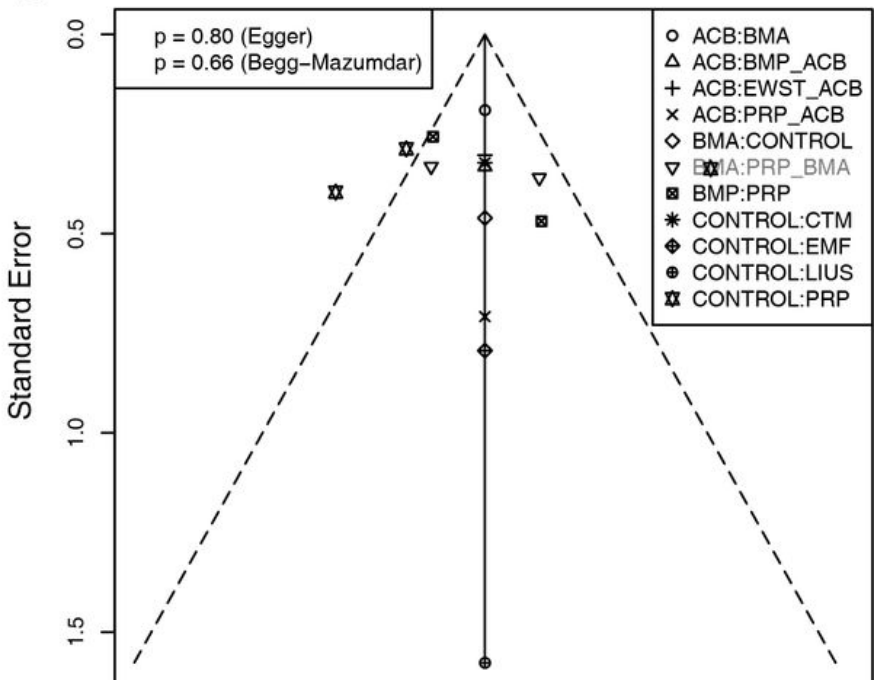

Figure 5

Comparison-adjusted funnel plots of each outcome in the network meta-analysis. A: healing rate; $\mathrm{B}$ : healing time. 